\title{
Evaluation of Mulch and Preemergence Herbicide Combinations for Weed Control in High-density Olive (Olea europaea L.) Production
}

\author{
Gerald M. Henry ${ }^{1}$ and Jared A. Hoyle \\ Department of Crop and Soil Sciences, University of Georgia, 3111 Miller \\ Plant Sciences Building, Athens, GA 30602
}

\author{
Leslie L. Beck, Tyler Cooper, Thayne Montague, \\ and Cynthia McKenney \\ Department of Plant and Soil Science, Texas Tech University, Box 42122, \\ Lubbock, TX 79409
}

\section{Additional index words. orchards, phytotoxicity}

Abstract. Field experiments were conducted at the Central Texas Olive Ranch in Walburg, TX, in 2011 and 2012 to evaluate the efficacy of mulch and/or preemergence herbicides for weed control in high-density olive (Olea europaea L.) production during orchard establishment. Treatments were initiated on 1 Apr. 2011 and 28 Mar. 2012 and consisted of a nontreated control, isoxaben ( $2.2 \mathrm{~kg}$ a.i./ha), oryzalin $(4.5 \mathrm{~kg}$ a.i./ha), oxadiazon $(3.36 \mathrm{~kg}$ a.i./ha), and mesotrione (0.14 $\mathrm{kg}$ a.i./ha). Hardwood mulch was applied to half of each plot following herbicide application. Weed counts, combined across species (camphorweed, texas croton, lanceleaf sage, pinnate tansymustard, tumble pigweed, common purslane, and prostrate spurge), were conducted to assess \% weed cover at 4 and 12 weeks after treatment (WAT). In 2011, compared with the nonmulched no herbicide treatment, adding mulch reduced weed counts by 23 and increased weed control by $70 \% 4$ WAT. All preemergence herbicide treatments, regardless of mulching regime, resulted in $\geq 97 \%$ weed control 4 WAT with the exception of oryzalin without mulch $(91 \%$ weed control, 3 weeds/plot). In 2012, compared with the nonmulched no herbicide treatment, adding mulch reduced weed counts by 35 and increased weed control by $64 \% 4$ WAT. Mulching in combination with mesotrione resulted in $\mathbf{1 0 0} \%$ weed control, significantly greater than mesotrione applied without mulch $(98 \%, 2$ weeds/plot) 4 WAT. Oryzalin without mulch resulted in greater weed control $(94 \%$, 4 weeds/plot) in $20124 \mathrm{WAT}$; however, this treatment provided the least amount of weed control of all preemergence herbicides tested. By 12 WAT, weed counts were reduced by 21 and 22 in 2011 and 2012, respectively, in response to mulching in the nontreated plots resulting in a $52 \%$ and $42 \%$ increase in weed control in 2011 and 2012 , respectively. Mesotrione was the only treatment affected by mulching regime 12 WAT in 2011 and 2012. Mesotrione in combination with mulch resulted in $100 \%$ weed control in 2011 and 2012, while mesotrione without mulch resulted in $93 \%$ weed control (3 and 4 weeds/plot) 12 WAT in 2011 and 2012, respectively. Although not statistically significant, isoxaben applied alone in 2011 resulted in $97 \%$ weed control (1 weed/plot), while isoxaben in combination with mulch resulted in $94 \%$ weed control (3 weeds/plot) 12 WAT. In 2011, oryzalin and oxadiazon resulted in $87 \%$ to $92 \%$ control, regardless of mulching regime 12 WAT. Weed control in response to isoxaben in 2012 was $95 \% 12$ WAT, regardless of mulching regime. The combination of oxadiazon + mulch resulted in similar weed control (95\%, 3 weeds/plot) 12 WAT; however, oxadiazon alone and oryzalin with and without mulch resulted in $87 \%$ to $89 \%$ weed control. All preemergence herbicides evaluated provided good to excellent weed control. Isoxaben and oryzalin are labeled for use on nonbearing fruit trees or during orchard establishment, while oxadiazon is only labeled for woody ornamentals. Although not labeled for use in orchards, mesotrione may be an alternative for use in olive production. The addition of mulching did not increase weed control except when used in conjunction with mesotrione. Mulch alone provided moderate weed control when preemergence herbicides were not applied. Furthermore, the utilization of mulch in combination with preemergence herbicides may help reduce photodegradation and/or volatilization when irrigation/rainfall is limited.

Olive (Olea europaea L.) orchard plantings have increased in Texas over the past 10 to 15 years primarily southwest of San Antonio and in the Hill Country (Stein et al., 2013). Olives have historically been produced under dryland conditions with trees spaced widely apart (173 trees/ha) to reduce intraspecific competition for stored soil water reserves (Rapoport et al., 2004; Vossen, 2007). In the early 1980s, irrigated orchards were planted in high densities (617 trees/ha) in attempts to reach full production quicker, reduce alternate-bearing behavior, and increase olive yields (Beede and Goldhamer, 1994; Pastor, 1994; Tous et al., 1999). Varieties used in high-density olive orchards are pruned to a central leader and staked with a pole for support (Stein et al., 2013; Vossen, 2007). The tree canopy starts $\approx 0.6 \mathrm{~m}$ above the orchard floor with plants reaching a maximum height of $2.1 \mathrm{~m}$ (Stein et al., 2013; Vossen, 2007). Although high-density systems increase olive yields, trees may still require 8 to 10 years to reach full production, harvest costs are high, mechanical hedging often reduces tree vigor, and pest control is more difficult in such a compact system (Civantos Lopez Villalta, 1998; Vossen, 2002).

Proper weed control practices are critical in olive orchards to reduce competition for valuable inputs such as water, nutrients, and sunlight, as well as to reduce the likelihood of negative impacts from pests (insects, nematodes, and pathogens) residing on the orchard floor. Goff et al. (1991) reported less $\mathrm{K}, \mathrm{Ca}$, and $\mathrm{Mg}$ concentrations in pecan [Carya illinoinensis (Wangenh.) C. Koch] tree leaves growing in plots infested with weeds compared with plots where weeds were controlled through use of herbicides or cultivation practices. Less disease was observed in tomato (Solanum lycopersicum L.) production when weed control practices were implemented (Wszelaki et al., 2005). Killian and Meyer (1984) observed that the number of peaches [Prunus persica (L.) Batsch] damaged by cat-facing insects in herbicide-treated plots was significantly less than that of fruit sampled from nontreated control plots.

Plant competition can be most detrimental during the first few years of orchard establishment. Weed control efforts must be focused within close proximity to the base of olive trees. However, few preemergence herbicides are available for the effective control of weeds in olive orchards. Montemurro et al. (2002) observed adequate control of several broadleaf and grass weeds with preemergence applications of oxyfluorfen at $0.6 \mathrm{~kg}$ a.i./ha. Treated plots exhibited higher crop yields than weedy control plots with minimal olive tree phytotoxicity (Montemurro et al., 2002). Flumioxazin, isoxaben, indaziflam, oryzalin, oxyfluorfen, pendimethalin, diuron, and simazine are labeled for preemergence applications to orchards, but several of these herbicides may only be applied to nonbearing olive trees or during orchard establishment (UC Statewide IPM Program, 2014).

Weed control is often achieved or enhanced with applications of organic mulches (cereal straw, green waste, or composted wood chips) or synthetic mulches (polyethylene, polypropylene, or polyester) around the base of trees (UC Statewide IPM Program, 2014). Applications of cattail (Typha latifolia L.) and rice (Oryza sativa L.) mulch to the floor of a mandarin orange (Citrus reticulata Blanco) grove reduced weeds $85 \%$ to $98 \%$ compared with nonmulched plots (Abouziena et al., 2008). Burkhard et al. (2009) observed weed biomass reductions of $55 \%$ to $73 \%$ when 
highbush blueberries (Vaccinium corymbosum L.) were mulched with pine needles. Mulches not only reduce weed germination and growth by blocking light to the soil surface, but may aid in soil moisture retention during droughty periods of the growing season (Moody et al., 1963; Ramakrishna et al., 2006; Teasdale and Mohler, 1993; UC Statewide IPM Program, 2014; Wesson and Wareing, 1967). Cregg and Schutzki (2009) reported that mulch (pine bark, hardwood fines, cypress mulch, and color-enhanced ground pallets) applications increased soil moisture retention in several shrub species compared with no mulch + weed control treatments. Furthermore, covering preemergence applications with mulch may reduce photodegradation, volatilization, and/or runoff of herbicides that remain at the soil surface, especially when irrigation or rainfall is limited (Mickelson et al., 2001). Wooten and McWhorter (1961) observed better weed control with subsurface applications of S-ethyl dipropylthiocarbamate using a horizontal blade applicator compared with surface applications of the same herbicide. Less herbicide runoff of atrazine, metolachlor, and cyanazine were observed in response to herbicide incorporation into the soil compared with notill surface applications (Mickelson et al., 2001). Therefore, further investigation of preemergence herbicides in combination with mulch for weed control in olive orchards is warranted. Identification of improved weed control techniques will enhance olive tree health and annual olive yield.

\section{Materials and Methods}

Field experiments were conducted at the Central Texas Olive Ranch in Granger, TX, in the spring and summer of 2011 and 2012 to evaluate the efficacy of mulch and/or preemergence herbicides for weed control in high-density olive production. Studies were conducted on 3-year-old nonbearing olive trees (oil production) grown on a Houston Black (fine, smectitic, thermic Udic Haplusterts) soil with a $\mathrm{pH}$ of 7.6 . Irrigation $(2 \mathrm{gal} / \mathrm{h})$ was supplied through drip irrigation (2 emitters/tree) to the base of each olive tree. Plots measured $1.8 \times 4.8 \mathrm{~m}$ and were arranged in a $2 \times 5$ factorial (two mulching regimes and five herbicides) within a randomized complete block design with four replications. Each plot contained four 'Koroneiki' olive trees spaced $1.2 \mathrm{~m}$ apart. Preemergence herbicide treatments were applied up to $15 \mathrm{~cm}$ from the base of each tree using a $\mathrm{CO}_{2}$ backpack sprayer

Received for publication 8 Aug. 2013. Accepted for publication $13 \mathrm{Feb} .2015$.

We wish to thank the Texas Department of Agriculture for funding this research and the Central Texas Olive Ranch for the use of their orchard. Mention of trade names or commercial products in this publication is solely for the purpose of providing specific information and does not imply recommendation or endorsement by the University of Georgia. ${ }^{1}$ Corresponding author. E-mail: gmhenry@uga.edu. equipped with two XR8003VS nozzle tips (Teejet; Spraying Systems Co., Wheaton, IL) calibrated to deliver $304 \mathrm{~L} \cdot \mathrm{ha}^{-1}$ at $275 \mathrm{kPa}$. Treatments (applied to bare ground) were initiated on 1 Apr. 2011 and 28 Mar. 2012 and consisted of isoxaben (Gallery; Dow AgroSciences, Indianapolis, IN) at $2.2 \mathrm{~kg}$ a. i./ha, oryzalin (Surflan; United Phosphorous, King of Prussia, PA) at $4.5 \mathrm{~kg}$ a.i./ha, oxadiazon (Ronstar FLO; Bayer Environmental Science, Research Triangle Park, NC) at $3.36 \mathrm{~kg}$ a.i./ha, and mesotrione (Tenacity; Syngenta Professional Products, Greensboro, NC) at $0.14 \mathrm{~kg}$ a.i./ha. Plots were irrigated following herbicide application with $\approx 0.6 \mathrm{~cm}$ of water to ensure activation of herbicides in the soil profile. Hardwood bark mulch (Evergreen, Muscle Shoals, AL) (to a depth of $6 \mathrm{~cm}$ ) was applied to the back $2.4 \mathrm{~m}$ of each plot, immediately after irrigation. A nontreated control with and without mulch was included for comparison.

Olive tree phytotoxicity (leaves only) was evaluated visually at 1 and 4 WAT on a scale of $0 \%$ (no phytotoxicity) to $100 \%$ (complete olive plant death). Weed counts were conducted to assess weed cover 1, 2, 4, 8, and 12 WAT. Each weed was counted within each plot. Although several weed species (camphorweed [Heterotheca subaxillaris (Lam.) Britt. \& Rusby] - annual broadleaf, texas croton [Croton texensis (Klotzsch) Muell.Arg. Ex DC.] - annual broadleaf, lanceleaf sage (Salvia reflexa Hornem.) - annual broadleaf, pinnate tansymustard [Descurainia pinnata (Walt.) Britt.] — annual broadleaf, tumble pigweed (Amaranthus albus L.)-annual broadleaf, common purslane (Portulaca oleracea L.) - annual broadleaf, and prostrate spurge [Chamaesyce humistrata (Engelm. Ex Gray) Small] — annual broadleaf $\}$ were observed in the research area, weed counts were combined across species to generate total weed counts. Percent control for each treatment was calculated relative to the control treatment within each replication and experimental run using the following equation:

$$
\% C=\frac{N-T}{N}
$$

where $C$ is the control, $N$ is the total number of weeds per plot in the control treatment, and $T$ is the total number of weeds per plot in the treated plot (Hoyle et al., 2012). Percentage control was reported on a scale of 0 to 100 , where 0 represents no weed control, and 100 represents complete weed control.

Analysis was conducted separately for rating dates and for each evaluation method. Weed counts and weed control data were arcsine square-root transformed to stabilize variance as described by Bowley (2008) before being subjected to analysis of variance (ANOVA) in SAS (version 9.2; SAS Institute, Cary, NC) using error partitioning appropriate to a split plot analysis in the general linear models procedure. Interpretations were not different from nontransformed data; therefore, nontransformed means are presented for clarity. All data were subjected to ANOVA in SAS using the appropriate expected mean square values described by McIntosh (1983). Treatment means were separated using Fisher's protected least significant difference test at $\alpha=0.05$.

\section{Results and Discussion}

A significant experimental run-bytreatment interaction was observed at 4 and 12 WAT $(F=5.34, P=0.001 ; F=4.26, P=$ 0.001 ; respectively); therefore, data were not pooled across years, and are presented separately. No $O$. europaea phytotoxicity was observed throughout the length of the trials, regardless of preemergence herbicide and/or mulching treatment (data not shown).

Significant herbicide and mulching main effects as well as an interaction between herbicide and mulching regime were observed for weed counts and weed control at 4 and 12 WAT in 2011 and 2012 (Tables 1 and 2). In 2011, compared with the nonmulched no herbicide treatment, adding mulch reduced weed counts by 23 and increased weed control by $70 \% 4$ WAT (Table 1 ). No other treatments resulted in significant weed count or weed control differences between mulching regimes in 20114 WAT. All preemergence herbicide treatments, regardless of mulching regime, resulted in $\geq 97 \%$ weed control 4 WAT with the exception of oryzalin at $4.5 \mathrm{~kg}$ a.i./ha without mulch (91\% weed control, 3 weeds/ plot). In 2012, compared with the nonmulched no herbicide treatment, adding mulch reduced weed counts by 35 and increased weed control by $64 \% 4$ WAT (Table 1). Mulching in combination with mesotrione at $0.14 \mathrm{~kg}$ a.i./ ha resulted in $100 \%$ weed control, significantly greater than mesotrione applied without mulch (98\%, 2 weeds/plot) 4 WAT. In 2012, mulching did not increase weed control in any other herbicide treatment 4 WAT, but weed counts were reduced by all treatments. Oryzalin at $4.5 \mathrm{~kg}$ a.i./ha without mulch resulted in greater weed control $(94 \%, 4$ weeds/plot) in 20124 WAT; however, this treatment provided the least amount of weed control of all preemergence herbicides tested. Arnold and Aldrich (1979) observed similar control of camphorweed (96\%) 4 WAT in an immature peach orchard in response to oryzalin + paraquat at $4.5+0.6 \mathrm{~kg}$ a.i./ha. However, camphorweed control $(88 \%)$ with oxadiazon + paraquat at $2.2+0.6 \mathrm{~kg}$ a.i./ha and $4.5+0.6 \mathrm{~kg}$ a.i./ha was less than that observed in our research (97\%) 4 WAT (Arnold and Aldrich, 1979). Setyowati et al. (1995) reported similar control ( $98 \%$ to $100 \%) 6$ WAT of broadleaf and annual grass weeds in field-grown landscape crops with oryzalin at $3.36 \mathrm{~kg}$ a.i./ha in 1991 , but slightly less control ( $84 \%$ to $88 \%$ ) in 1990. Lower rates of isoxaben $(0.84 \mathrm{~kg}$ a.i./ha) resulted in equivalent weed control $(87 \%$ to $100 \%)$ as observed in our research $(97 \%$ to $100 \%)$. At 8 WAT, Neal and Senesac (1990) reported comparable weed control $(95 \%$ and $100 \%$ ) of broadleaf weeds (common purslane, Amaranthus spp., etc.) present in containergrown ornamentals in response to oryzalin at $4.5 \mathrm{~kg}$ a.i./ha and isoxaben at $2.2 \mathrm{~kg}$ a.i./ha, respectively. 
Table 1. Weed control and weed counts as influenced by herbicide and mulching interaction in 2011 and 2012 at 4 WAT. $^{\mathrm{z}}$

\begin{tabular}{|c|c|c|c|c|c|c|c|c|}
\hline \multirow[b]{2}{*}{$\mathrm{Yr}$} & \multirow[b]{2}{*}{ Herbicide } & \multirow[b]{2}{*}{ Rate (kg a.i./ha) } & \multicolumn{3}{|c|}{ Weed counts (per $\left.2.3 \mathrm{~m}^{2}\right)^{\mathrm{y}}$} & \multicolumn{3}{|c|}{ Control (\%) } \\
\hline & & & No mulch & Mulched & LSD & No mulch & Mulched & $\overline{\mathrm{LSD}}$ \\
\hline \multirow[t]{6}{*}{2011} & Nontreated & & $33 \mathrm{Aa}^{\mathrm{w}}$ & $10 \mathrm{Ab}$ & 8 & $0 \mathrm{Cb}$ & $70 \mathrm{Ba}$ & $\overline{9}$ \\
\hline & Isoxaben & 2.2 & $0 \mathrm{Ba}$ & $0 \mathrm{Ba}$ & 0 & $100 \mathrm{Aa}$ & $100 \mathrm{Aa}$ & 0 \\
\hline & Mesotrione & 0.14 & $0 \mathrm{Ba}$ & $0 \mathrm{Ba}$ & 0 & $100 \mathrm{Aa}$ & $100 \mathrm{Aa}$ & 0 \\
\hline & Oryzalin & 4.5 & $3 \mathrm{Ba}$ & $1 \mathrm{Ba}$ & 3 & $91 \mathrm{Ba}$ & $97 \mathrm{Aa}$ & 9 \\
\hline & Oxadiazon & 3.36 & $1 \mathrm{Ba}$ & $1 \mathrm{Ba}$ & 2 & $97 \mathrm{Aa}$ & $97 \mathrm{Aa}$ & 5 \\
\hline & $\operatorname{LSD}_{(0.05)}$ & & 5 & 2 & & 5 & 7 & \\
\hline \multirow[t]{6}{*}{2012} & Nontreated & & $55 \mathrm{Aa}$ & $20 \mathrm{Ab}$ & 17 & $0 \mathrm{Cb}$ & $64 \mathrm{Ba}$ & 13 \\
\hline & Isoxaben & 2.2 & $2 \mathrm{Ba}$ & $0 \mathrm{Ba}$ & 2 & $97 \mathrm{Aa}$ & $100 \mathrm{Aa}$ & 3 \\
\hline & Mesotrione & 0.14 & $2 \mathrm{Ba}$ & $0 \mathrm{Bb}$ & 1 & $98 \mathrm{Ab}$ & $100 \mathrm{Aa}$ & 1 \\
\hline & Oryzalin & 4.5 & $4 \mathrm{Ba}$ & $3 \mathrm{Ba}$ & 3 & $94 \mathrm{Ba}$ & $95 \mathrm{Aa}$ & 5 \\
\hline & Oxadiazon & 3.36 & $3 \mathrm{Ba}$ & $3 \mathrm{Ba}$ & 3 & $95 \mathrm{Aba}$ & $95 \mathrm{Aa}$ & 5 \\
\hline & $\operatorname{LSD}_{(0.05)}$ & & 9 & 4 & & 3 & 8 & \\
\hline
\end{tabular}

${ }^{\mathrm{z}} \mathrm{WAT}$, weeks after treatment; LSD, least significant difference.

${ }^{\mathrm{y}}$ Weeds present in plots consisted of camphorweed [Heterotheca subaxillaris (Lam.) Britt. \& Rusby], texas croton [Croton texensis (Klotzsch) Muell.-Arg. Ex DC.], lanceleaf sage (Salvia reflexa Hornem.), pinnate tansymustard [Descurainia pinnata (Walt.) Britt.], tumble pigweed (Amaranthus albus L.), common purslane (Portulaca oleracea L.), and prostrate spurge [Chamaesyce humistrata (Engelm. Ex Gray) Small].

${ }^{x}$ Percent control for each herbicide and mulching combination was calculated by each replication within each experimental run from total relative weed counts.

${ }^{\text {w}}$ Means within a column followed by the same uppercase letter are not significantly different at $P \leq 0.05$, according to Fisher's protected LSD test. Means within a row followed by the same lowercase letter are not significantly different at $P \leq 0.05$ according to Fisher's protected LSD test.

Table 2. Weed control and weed counts as influenced by herbicide and mulching interaction in 2011 and 2012 at 12 WAT. $^{2}$

\begin{tabular}{|c|c|c|c|c|c|c|c|c|}
\hline \multirow[b]{2}{*}{$\mathrm{Yr}$} & \multirow[b]{2}{*}{ Herbicide } & \multirow[b]{2}{*}{ Rate (kg a.i./ha) } & \multicolumn{3}{|c|}{ Weed counts $\left(\text { per } 2.3 \mathrm{~m}^{2}\right)^{\mathrm{y}}$} & \multicolumn{3}{|c|}{ Control $(\%)^{x}$} \\
\hline & & & No mulch & Mulched & LSD & No mulch & Mulched & LSD \\
\hline \multirow[t]{6}{*}{2011} & Nontreated & & $41 \mathrm{Aa}^{\mathrm{w}}$ & $20 \mathrm{Ab}$ & 9 & $0 \mathrm{Cb}$ & $52 \mathrm{Ca}$ & 5 \\
\hline & Isoxaben & 2.2 & $1 \mathrm{Ba}$ & $3 \mathrm{BCa}$ & 4 & $97 \mathrm{Aa}$ & $94 \mathrm{ABa}$ & 8 \\
\hline & Mesotrione & 0.14 & $3 \mathrm{Ba}$ & $0 \mathrm{Cb}$ & 2 & $93 \mathrm{ABb}$ & $100 \mathrm{Aa}$ & 6 \\
\hline & Oryzalin & 4.5 & $4 \mathrm{Ba}$ & $4 \mathrm{Ba}$ & 4 & $90 \mathrm{Ba}$ & $90 \mathrm{Ba}$ & 9 \\
\hline & Oxadiazon & 3.36 & $5 \mathrm{Ba}$ & $3 \mathrm{BCa}$ & 3 & $87 \mathrm{Ba}$ & $92 \mathrm{Ba}$ & 9 \\
\hline & $\operatorname{LSD}_{(0.05)}$ & & 5 & 3 & & 6 & 7 & \\
\hline \multirow[t]{6}{*}{2012} & Nontreated & & $53 \mathrm{Aa}$ & $31 \mathrm{Ab}$ & 10 & $0 \mathrm{Db}$ & $42 \mathrm{Ca}$ & 11 \\
\hline & Isoxaben & 2.2 & $3 \mathrm{Ba}$ & $3 \mathrm{BCa}$ & 3 & $95 \mathrm{Aa}$ & $95 \mathrm{ABa}$ & 5 \\
\hline & Mesotrione & 0.14 & $4 \mathrm{Ba}$ & $0 \mathrm{Cb}$ & 2 & $93 \mathrm{ABb}$ & $100 \mathrm{Aa}$ & 4 \\
\hline & Oryzalin & 4.5 & $7 \mathrm{Ba}$ & $6 \mathrm{Ba}$ & 4 & $87 \mathrm{Ca}$ & $89 \mathrm{Ba}$ & 9 \\
\hline & Oxadiazon & 3.36 & $6 \mathrm{Ba}$ & $3 \mathrm{BCa}$ & 3 & $89 \mathrm{BCa}$ & $95 \mathrm{ABa}$ & 6 \\
\hline & $\operatorname{LSD}_{(0.05)}$ & & 5 & 4 & & 5 & 8 & \\
\hline
\end{tabular}

${ }^{\mathrm{z}}$ WAT, weeks after treatment; LSD, least significant difference.

${ }^{\mathrm{y}}$ Weeds present in plots consisted of camphorweed [Heterotheca subaxillaris (Lam.) Britt. \& Rusby], texas croton [Croton texensis (Klotzsch) Muell.-Arg. Ex DC.], lanceleaf sage (Salvia reflexa Hornem.), pinnate tansymustard [Descurainia pinnata (Walt.) Britt.], tumble pigweed (Amaranthus albus L.), common purslane (Portulaca oleracea L.), and prostrate spurge [Chamaesyce humistrata (Engelm. Ex Gray) Small].

'Percent control for each herbicide and mulching combination was calculated by each replication within each experimental run from total relative weed counts.

${ }^{\text {w}}$ Means within a column followed by the same uppercase letter are not significantly different at $P \leq 0.05$, according to Fisher's protected LSD test. Means within a row followed by the same lowercase letter are not significantly different at $P \leq 0.05$ according to Fisher's protected LSD test.

Differences in herbicide efficacy among treatments were more pronounced $12 \mathrm{WAT}$ (Table 2). Similar to 4 WAT, weed counts were reduced by 21 and 22 in 2011 and 2012, respectively, in response to mulching in the nontreated plots. This resulted in a $52 \%$ and $42 \%$ increase in weed control 12 WAT in 2011 and 2012, respectively (Table 2). Brown and Tworkoski (2004) reported even higher reductions in weed pressure (92\%) 16 WAT in response to hardwood mulch applied to a depth of $6 \mathrm{~cm}$ in a 16-year-old apple (Malus domestica Borkh.) orchard. However, control with wood chip mulch in field-grown herbaceous perennials was only $3 \% 20$ WAT, regimes 12 WAT in 2011 and 2012. Armel et al. (2003) observed less control of smooth pigweed (Amaranthus hybridus L.) (68\% to $82 \%$ ) and common ragweed (Ambrosia artemisiifolia L.) $(68 \%$ to $79 \%)$ in response to mesotrione at $0.15 \mathrm{~kg}$ a.i./ha, but similar control of common lambsquarters (Chenopodium album L.) (88\% to 93\%) 12 WAT. Nurse et al. (2010) reported that it required doses of mesotrione at 10 to $1984 \mathrm{~g}$ a.i./ha, $45 \mathrm{~g}$ a.i./ha, 19 to $243 \mathrm{~g}$ a.i./ha, and $288 \mathrm{~g}$ a.i./ha to control $90 \%$ of the biomass of common lambsquarters, common ragweed, redroot pigweed (Amaranthus retroflexus L.), and velvetleaf (Abutilon theophrasti Medik.), respectively.

Isoxaben at $2.2 \mathrm{~kg}$ a.i./ha applied alone in 2011 resulted in 97\% weed control (1 weed/ plot), while isoxaben in combination with mulch resulted in $94 \%$ weed control (3 weeds/plot) 12 WAT. In 2011, oryzalin at $4.5 \mathrm{~kg}$ a.i./ha and oxadiazon at $3.36 \mathrm{~kg}$ a.i./ha resulted in $87 \%$ to $92 \%$ control, regardless of mulching regime 12 WAT. Weed control in response to isoxaben at $2.2 \mathrm{~kg}$ a.i./ha in 2012 was $95 \% 12$ WAT, regardless of mulching regime. The combination of oxadiazon at $3.36 \mathrm{~kg}$ a.i./ha + mulch resulted in similar weed control (95\%, 3 weeds/plot) 12 WAT; however, oxadiazon alone and oryzalin at $4.5 \mathrm{~kg}$ a.i./ha with and without mulch resulted in $87 \%$ to $89 \%$ weed control. Derr (1994) observed similar control $(91 \%$ to $100 \%)$ of spotted spurge [Chamaesyce maculata (L.) Small] and yellow woodsorrel (Oxalis stricta L.) present in container-grown herbaceous perennials in response to oryzalin at $4.5 \mathrm{~kg}$ a.i./ha and oxadiazon at $4.5 \mathrm{~kg}$ a.i./ha $12 \mathrm{WAT}$. Staats and Klett (1993) reported $>99 \%$ and $92 \%$ control of broadleaf and annual grass weeds at the end of the season in response to oxadiazon at $4.5 \mathrm{~kg}$ a.i./ha and oryzalin at $2.8 \mathrm{~kg}$ a.i./ha. However, isoxaben at $2.3 \mathrm{~kg}$ a.i./ha only resulted in $43 \%$ weed control (Staats and Klett, 1993). Reeder et al. (1994) reported poor control of sicklepod (Cassia obtusifolia L.) $(13 \%$ to $28 \%) 90 \mathrm{~d}$ after treatment (DAT) and $0 \%$ control of cutleaf evening primrose (Oenothera laciniata Hill) 60 DAT in response to oryzalin at $3.4 \mathrm{~kg}$ a.i./ha applied to field-grown woody ornamentals. Calkins et al. (1996) observed $23 \%, 36 \%$, and $79 \%$ control of broadleaf and grass weeds $\approx 20$ WAT in response to isoxaben at $1.12 \mathrm{~kg}$ a.i./ha, oxadiazon at $3.92 \mathrm{~kg}$ a.i./ha, and oryzalin at $3.36 \mathrm{~kg}$ a.i./ha, respectively, in field-grown herbaceous perennials. Although similar weeds were present (common purslane and Amaranthus spp.), isoxaben and oryzalin rates were lower and control ratings were recorded 2 months later than our research.

Differential responses in weed control with preemergence herbicides may be related to differences in weed pressure in 2011 and 2012. Weed counts in nontreated control plots was 33 to 41 in 2011 and 53 to 55 in 2012. Lower weed pressure in 2011 may be linked to the severe drought conditions experienced that year. The average Palmer drought severity index in Texas during the Summer of 2011 (June through August) was 
-5.37 , indicating the most severe drought since 1895 (Dawson, 2011). Although olive trees were irrigated, water from the drip irrigation emitters was focused directly at the base of the trees. High temperatures and low humidity during spring and summer months may have increased evaporative demand thus reducing weed germination and seedling plant vigor.

All preemergence herbicides evaluated provided good to excellent weed control in high-density olive production without causing phytotoxicity. Isoxaben and oryzalin are labeled for use on nonbearing fruit trees and during orchard establishment, while oxadiazon is only labeled for woody ornamentals. Although not labeled for use in orchards, mesotrione may be an alternative for use in olive production. The addition of mulching did not increase weed control except when used in conjunction with mesotrione. Mulch alone provided moderate weed control when preemergence herbicides were not applied. Furthermore, the utilization of mulch in combination with preemergence herbicides may help reduce photodegradation and/or volatilization when irrigation/rainfall is limited.

\section{Literature Cited}

Abouziena, H.F., O.M. Hafez, I.M. El-Metwally, S.D. Sharma, and M. Singh. 2008. Comparison of weed suppression and mandarin fruit yield and quality obtained with organic mulches, synthetic mulches, cultivation, and glyphosate. HortScience 43:795-799.

Armel, G.R., H.P. Wilson, R.J. Richardson, and T.E. Hines. 2003. Mesotrione combinations in no-till corn (Zea mays). Weed Technol. 17:111-116.

Arnold, C.E. and J.H. Aldrich. 1979. Weed control in immature pecan (Carya illinoensis) and peach (Prunus persica) plantings. Weed Sci. 27:638-641.

Beede, R.H. and D. Goldhamer. 1994. Olive irrigation management, p. 61-68. In: L. Ferguson, G.S. Sibbett, and G.C. Martin (eds.). Olive production manual. Univ. Calif. Div. Agr. Natrl. Resour., Oakland, CA, Publ. 3353.

Bowley, S.R. 2008. A hitchhiker's guide to statistics in plant biology. 2nd ed. Any Old Subject Books, Ontario, Canada. p. 1-266.

Brown, M.W. and T. Tworkoski. 2004. Pest management benefits of compost mulch in apple orchards. Ag. Ecosys. Environ. 103:465-472.
Burkhard, N., D. Lynch, D. Percival, and M. Sharifi. 2009. Organic mulch impact on vegetation dynamics and productivity of highbush blueberry under organic production. HortScience 44:688-696.

Calkins, J.B., B.T. Swanson, and D.L. Newman 1996. Weed control strategies for field grown herbaceous perennials. J. Environ. Hort. 14:221-227.

Civantos Lopez Villalta, L. 1998. The olive tree, the oil, the olive. International Olive Oil Council. ADICOM, Madrid, Spain.

Cregg, B.M. and R. Schutzki. 2009. Weed control and organic mulches affect physiology and growth of landscape shrubs. HortScience 44:1419-1424.

Dawson, B. 2011. A drought for the centuries: It hasn't been this dry in Texas since 1789. Texas Climate News. 19 Dec. 2011. <http://texasclimatenews.org/wp/?p=3355>

Derr, J.F. 1994. Weed control in container-grown herbaceous perennials. HortScience 29:95-97.

Goff, W.D., M.G. Patterson, and M.S. West. 1991. Orchard floor management practices influence elemental concentrations in young pecan trees. HortScience 26:1379-1381.

Hoyle, J.A., J.S. McElroy, and J.J. Rose. 2012. Weed control using an enclosed thermal heating apparatus. Weed Technol. 26:699707.

Killian, J.C. and J.R. Meyer. 1984. Effect of weed management on catfacing damage to peaches in North Carolina. J. Econ. Entomol. 77:15961600.

McIntosh, M.S. 1983. Analysis of combined experiments. Agron. J. 75:153-155.

Mickelson, S.K., S. Anton, J.L. Baker, and S.I. Ahmed. 2001. Subsurface herbicide application with the modified John Deere mulch master. Trans. ASAE 44:807-812.

Montemurro, P., M. Fracchiolla, D. Guarini, and C. Lasorella. 2002. Results of a chemical weed control trial in an oil olive orchard. Acta Hort. 586:397-400

Moody, J.E., J.N. Jones, and J.H. Lillard. 1963. Influence of straw mulch on soil moisture, soil temperature and the growth of corn. Soil Sci. Soc. Amer. J. 27:700-703.

Neal, J.C. and A.F. Senesac. 1990. Preemergent weed control in container and field grown woody nursery crops with Gallery. J. Environ. Hort. 8:103-107.

Nurse, R.E., A.S. Hamill, C.J. Swanton, F.J. Tardif, and P.H. Sikkema. 2010. Weed control and yield response to mesotrione in maize (Zea mays). Crop Prot. 29:652-657.
Pastor, M. 1994. Plantaciones intensivas de olivar. Agricultura 746:738-744.

Ramakrishna, A., H.M. Tam, S.P. Wani, and T.D Long. 2006. Effect of mulch on soil temperature, moisture, weed infestation and yield of groundnut in northern Vietnam. Field Crops Res. 96:115-125.

Rapoport, H.F., G. Costagli, and R. Gucci. 2004 The effect of water deficit during early fruit development on olive fruit morphogenesis. J. Amer. Soc. Hort. Sci. 129:121-127.

Reeder, J.E., C.H. Gilliam, G.R. Wehtje, D.B South, and G.J. Keever. 1994. Evaluation of selected herbicides on field-grown woody ornamentals. J. Environ. Hort. 12:236-240.

Setyowati, N., L.A. Weston, and R.E. McNiel. 1995. Evaluation of selected preemergence herbicides in field-grown landscape crops in Kentucky. J. Environ. Hort. 13:196-202.

Staats, D. and J.E. Klett. 1993. Evaluation of weed control and phytotoxicity of preemergence herbicides applied to container-grown herbaceous and woody plants. J. Environ. Hort. 11:78-80.

Stein, L., J. Kamas, and M. Nesbitt. 2013. Olives. Texas Fruit and Nut Production Fact Sheet. AgriLife Extension, Texas A\&M University, College Station, TX.

Teasdale, J.R. and C.L. Mohler. 1993. Light transmittance, soil temperature, and soil moisture under residue of hairy vetch and rye. Agron. J. 85:673-680

Tous, J.M., A. Romero, J. Plana, and F. Baiges. 1999. Planting density trial with 'Arbequina' olive cultivar in Catalonia (Spain). Proc. 3rd ISHS Symp. On Olive Growing. Acta Hort. 474:177-180.

UC Statewide IPM Program. 2014. UC IPM Pest Management Guidelines. University of California, Davis, CA. UC ANR Publication 3452.

Vossen, P. 2007. Olive oil: History, production, and characteristics of the world's classic oils. HortScience 42:1093-1100.

Vossen, P.M. 2002. Super-high-density olive oil production. OLINT Magazine 1:17-23. [special English edition].

Wesson, G. and P.F. Wareing. 1967. Light requirements of buried seed. Nature 21:600-601.

Wooten, O.B. and C.G. McWhorter. 1961. A device for the subsurface application of herbicides. Weeds 9:36-41.

Wszelaki, A., S. Miller, D. Doohan, K. Amisi, B. McSpadden-Gardener, and M. Kleinhenz. 2005. Fertility and weed management effects on crop quality and disease variables in a transitionalorganic processing cabbage and tomato system. HortScience 40:1093. 